А.В. Бондар ${ }^{1}$, Г.О. Шумілін ${ }^{1}$, Р.Г. Агамова ${ }^{1}$

${ }^{1}$ Державний науково-дослідний інститут авіаиії, Київ

\title{
ОБГРУНТУВАННЯ УМОВ, ПОТРЕБИ (ДОЦІЛЬНОСТІ) ТА МОЖЛИВОСТІ ЗБІЛЬШЕННЯ (ПРОДОВЖЕННЯ ЗА ТЕХНІЧНИМ СТАНОМ) ВСТАНОВЛЕНОГО РЕСУРСУ ЧУТЛИВИХ ЕЛЕМЕНТІВ АВІАЦІЙНОГО ДВИГУНА АЛ-31Ф
}

У статті наведено аналіз роботи чутливих елементів АЧЭ-240, АЧЭ-202М, АЧМЭС-7, ТЖ-5, АЧЭ-99 авіаційних двигунів типу АЛ-31Ф. Експлуатація та ремонт авіаційних двигунів такого типу та їх вузлів 6 Украӥні відбувається за відсутності авторської підтримки з боку розробників $і$ виробників. В процесі ремонту двигунів типу АЛ-ЗІФ необхідно замінити агрегати з вичерпаним терміном служби на нові. Проведений авторами аналіз роботи чутливих елементів надає можливість збільшення встановленого ресурсу чутливих елементів АЧЭ-240, АЧЭ-202М, АЧМЭС-7, ТЖ-5, АЧЭ-99 при виконанні ремонту на авіаційному ремонтному підприємстві та прийняття обгрунтованого рішення для подальшого застосування їх на авіаџійних двигунах типу АЛ-31Ф.

Ключові слова: авіаційний двигун, чутливі елементи, стратегія управління ресурсом, встановлений ресурс, несправність.

\section{Вступ}

Постановка проблеми. У Повітряних Силах Збройних Сил України інтенсивність бойової підготовки збільшується, що підвищує боєздатність авіаційних частин, підрозділів, яка досягається та супроводжується зростанням нальоту літальних апаратів (далі - ЛА) та збільшенням наробітку парку авіаційних двигунів (далі - АД). Експлуатація і ремонт АД та їх компонентів в Україні відбувається в умовах відсутності авторського супроводження 3 боку підприємств-розробників і виробників.

Ресурси агрегатів і комплектуючих виробів повинні бути, як правило, однакові або перевищувати ресурс двигуна. Однак, деякі агрегати мають ресурс нижчий, ніж встановлений pecypc (BР) двигуна. Тому виникає питання щодо можливості використання цих агрегатів на наступний міжремонтний ресурс.

В процесі експлуатації агрегати працюють в різних діапазонах температур, тиску та навантажень. Тому і ресурс чутливі елементи мають різний.

При ремонті двигуна АЛ-31Ф доводиться заміняти агрегати і комплектувальні вироби (АіКВ) iз значним запасом установленого ресурсу та вичерпаним строком служби на нові [1, с. 276] Закупівля нових АіКВ ускладнюється тим, що, поперше, вони відносяться до виробів, які використовуються на військовій техніці, тому потребують спеціальних дозволів на проведення тендерів та ввозу до України. По-друге, в сучасних умовах постійно зростає ї ціна. Тому, дуже актуальним $є$ підхід використання АіКВ, які зберігаються на складах авіаремонтних підприємств (АРП) 3 достатніми запасами ресурсу та із закінченими встановленими строками служби. При цьому, вартість нових агрегатів набагато перевищує вартість 3 відновлення технічного стану агрегатів із закінченим строком служби, що значно впливає на вартість капітального ремонту. Для визначення можливості продовження встановленого ресурсу агрегатам, які експлуатуються в складі двигунів АЛ-31Ф, необхідно провести дослідження їх технічного стану при проходженні ними капітального ремонту в умовах АРП.

Відповідно до керівництва 3 капітального ремонту окрема перевірка параметрів агрегатів, що надходять у ремонт, при вхідному контролі не передбачена. Але на деяких типах агрегатів передбачена така перевірка у межах процедури дефектації перед початком розбирання. При дефектуванні заміряється ряд параметрів, що характеризують їх технічний стан. Якщо значення цих параметрів знаходяться в межах технічних вимог, то це свідчить про те, що агрегати, не зважаючи на вичерпаний або близький до граничного встановлений строк служби, залишаються справними i мають запас працездатності [2, с. 65...70].

Після виконання ремонту на кожному агрегаті проведено необхідні контрольні операції та випробування для визначення його технічного стану в цілому. Обсяг таких операцій та випробувань визначено для кожного типу агрегатів і наведено у відповідних контрольних картах.

Серед параметрів, що заміряються в процесі випробування агрегатів $є$ такі, що найбільш повно визначають вплив факторів на їх технічний стан, які пов'язані із строком служби.

Черговий (другий) капітальний ремонт (КР) АД дозволяє виявити окремі проблемні питання забезпечення подальшого підтримання льотної придатності заданої кількості літаків. Це, насамперед, обгрунтування технічної можливості збільшення встановленого ресурсу основних 
деталей двигунів, освоєння виготовлення їх в Україні в порядку імпортозаміщення та забезпечення безпечної експлуатації двигунів за технічним станом за наробітком.

Аналіз останніх досліджень і публікацій. На сьогоднішній день дослідження i публікації 3 окресленої в цьому напрямку не було.

Мета статті - дати об’єктивну оцінку для прийняття обгрунтованого рішення щодо визначення можливості подальшого продовження встановленого ресурсу агрегатам двигуна АЛ-31Ф.

\section{Виклад основного матеріалу}

На теперішній час більшість АіКВ АД АЛ-31Ф мають залишки встановленого ресурсу. Але, чутливі елементи (АМЧЭС-7, АЧЭ-99, АЧЭ-240, АЧЭ-202М) (рис.1) мають залишки встановленого ресурсу менші, ніж у двигуна. Це не дає можливості ix використання для наступного (другого) міжремонтного періоду експлуатації двигуна.
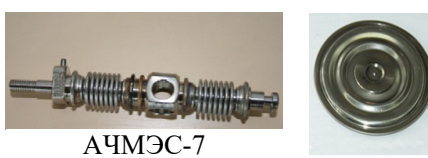

АЧЭ-99

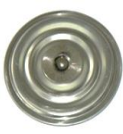

АЧЭ- 240
АЧЭ-202М

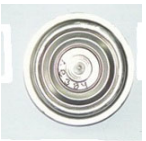

Рис. 1. Зовнішній вигляд АЧМЭС-7, АЧЭ-99, АЧЭ-240, АЧЭ-202М.

Джерело: сфотографовано авторами.

На сьогоднішній день двигун АЛ-31Ф має встановлений ресурс від 900 до 1200 годин в залежності від року випуску [3, с. 5].

Чутливі елементи авіаційного двигуна АЛ-31Ф, які потребують збільшення встановленого ресурсу представлені у табл. 1 [3, с. 5].

Таблиця 1.

Перелік чутливих елементів двигуна АЛ-31Ф, які

потребують збільшення встановленого ресурсу

\begin{tabular}{|c|l|l|c|}
\hline $\begin{array}{c}\text { № } \\
\text { п/п }\end{array}$ & Найменування виробу & Шифр & $\begin{array}{c}\text { Діючі } \\
\text { ресурси, } \\
\text { год. }\end{array}$ \\
\hline 1 & Чутливий елемент & АМЧЭС-7 & 800 \\
\hline 2 & Чутливий елемент & АЧЭ-240 & 800 \\
\hline 3 & Чутливий елемент & АЧЭ-202М & 800 \\
\hline 4 & Чутливий елемент & АЧЭ-99 & 700 \\
\hline 5 & $\begin{array}{l}\text { Термокомпенсатор } \\
\text { рідинний }\end{array}$ & ТЖ-5 & 800 \\
\hline
\end{tabular}

Джерело: розроблено авторами за даними [3, с. 4]

Для цього необхідне проведення досліджень щодо визначення можливості та умов поетапного збільшення ресурсу агрегатів АД АЛ-31Ф.

Чутливі елементи АМЧЭС-7, АЧЭ-202М, АЧЭ-99, АЧЭ-240 є елементами сильфонного (анероїдного) типу [4, с. 192...194; 5, с 109...142].

Принцип дії чутливих елементів заснований на формуванні сигналу у вигляді зусилля (переміщення) пропорційного перепаду тиску палива (повітря) на сильфоні (анероїді).

Чутливий елемент (сильфон) АМЧЭС-7 (рис. 2) працює в середовищі повітря у відсіку двигуна та під тиском $P_{k}^{*}$. Він розташований у вузлі агрегату НР-31В та виконує функцію управління витратою палива автомата приймання $[4$, с. $270 \ldots 273 ; 5$, c. $129 \ldots 135]$.

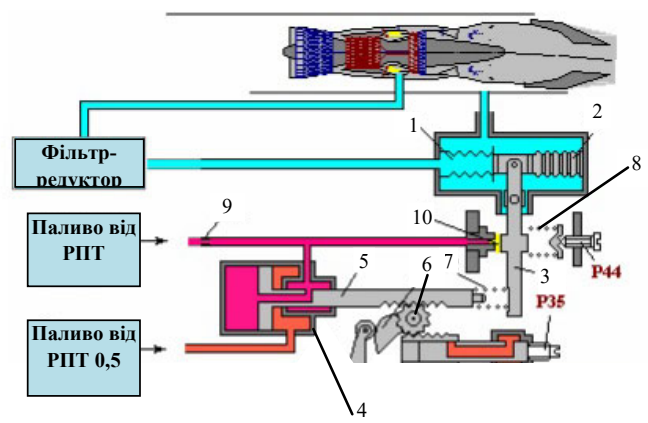

Рис. 2. Чутливий елемент АМЧЭС-7 (поз. 1, 2) у вузлі автомату приймання та обмежувача $P_{k}^{*}$ агрегатів НР-31B.

Джерело: розроблено авторами за даними [5, с. 134].

Випадків відмови агрегатів в експлуатації через руйнування чутливих елементів АМЧЭС-7 не було.

Чутливий елемент (анероїд) АЧЭ-99 (рис. 3) працює у відцентровому суфлері двигуна i призначений для підтримання тиску у системі

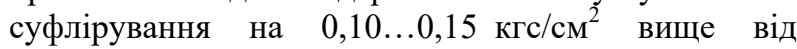
атмосферного, що необхідно для роботи відкачуючих маслонасосів у висотних умовах [4, c. $192 \ldots 194]$.

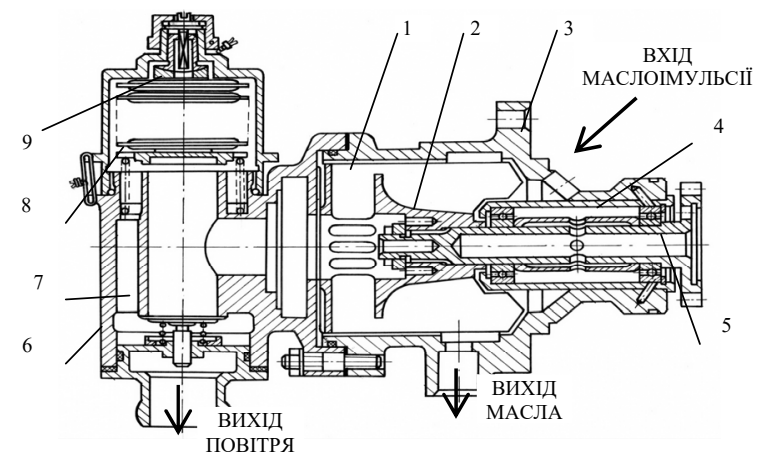

Рис. 3. Чутливий елемент АЧЭ-99 (поз. 9) у вузлі відцентрового суфлера системи змащення двигуна. Джерело: розроблено авторами за даними [4, с. 192].

Випадків відмови агрегатів в експлуатації через руйнування чутливих елементів АЧЭ-99 не було.

Відцентровий суфлер призначений для суфлювання до висот польоту $6 . .8$ км масляних порожнин опор роторів виносної коробки агрегатів, коробки агрегатів двигуна і масляного бака.

Після закриття баростатичного клапана в системі за допомогою зворотнього клапана підтримується тиск, надлишковий над атмосферним

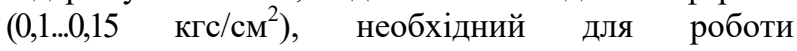
маслонасосів у висотних умовах.

Чутливий елемент (анероїд) АЧЭ-240 (рис. 4) розташований в автоматі запуску агрегату НР-31B, сприймає зміну тиску повітря у відсіку двигуна та перетворює iï у переміщення елементів автомату запуску, який дозує кількість палива, що подається 
до основної камери згорання на режимі “запуск” $[4$, c. $269 ; 5$, с. $138 \ldots 142]$.

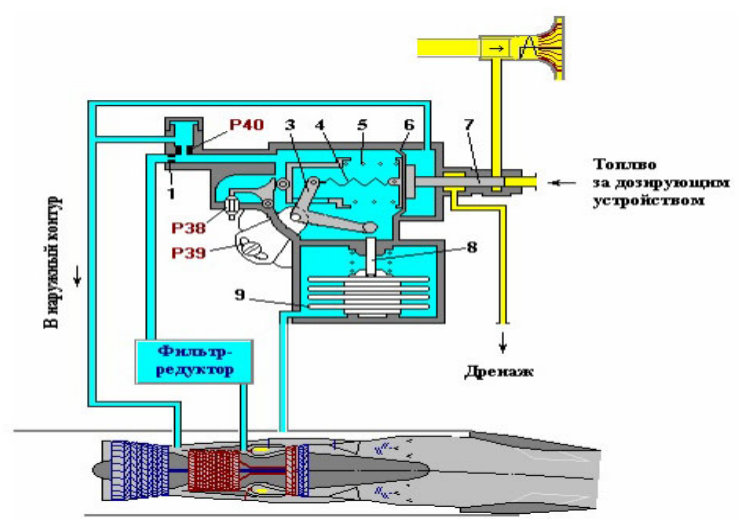

Рис. 4. Чутливий елемент АЧЭ- 240 (поз. 9).

Джерело: розроблено авторами за даними [5, с. 141].

3 ростом висоти польоту зусилля від мембрани, внаслідок натягу пружини пакетом анероїдів, збільшується і надлишки палива в процесі запуску на більшій висоті знижуються.

Випадків відмови агрегату в експлуатації через руйнування чутливого елементу АЧЭ-240 не було.

Чутливий елемент (анероїд) АЧЭ-202М (рис. 5) працює у коректорі мінімальної витрати агрегату НР-31B і сприймає зміну тиску повітря у відсіку двигуна та перетворює іiі у переміщення елементів вузла, який дозує кількість палива, що подається до основної камери згоряння на режимах "запуск" i “малий газ” [4, с. 276...277; 5, с. 109..112].

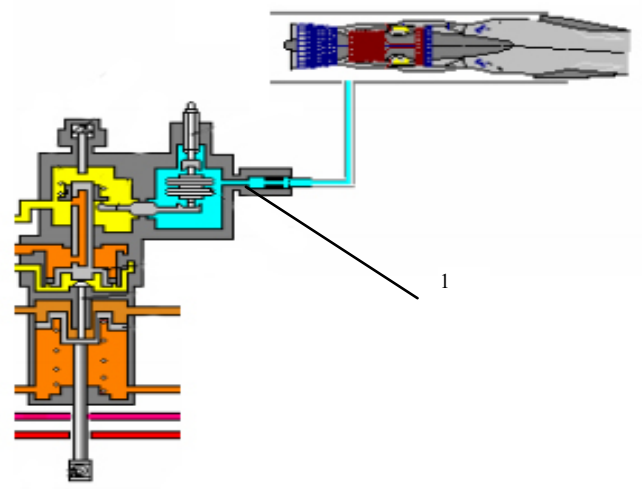

Рис. 5. Чутливий елемент АЧЭ- 240 (поз. 1).

Джерело: розроблено авторами за даними [4, с. 207].

Випадків відмови агрегату в процесі експлуатації через руйнування чутливого елементу АЧЭ-202М не було.

Термокомпенсатор ТЖ-5 диференційного клапану агрегату НР-31B призначений для додержання зусиль на пружині у вузлі агрегату при різних температурних подовженнях його деталей (рис. 6) $[4$, с. $207 \ldots 211,255 \ldots 256]$. Принцип дії заснований на виникненні зусилля гофрованого сильфона за рахунок його температурного подовження при зміні температури палива (рис. 7).

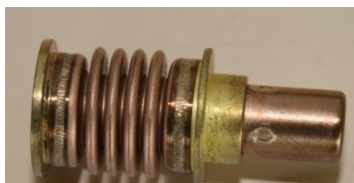

Рис. 6. Зовнішній вигляд ТЖ-5.

Джерело: сфотографовано авторами.

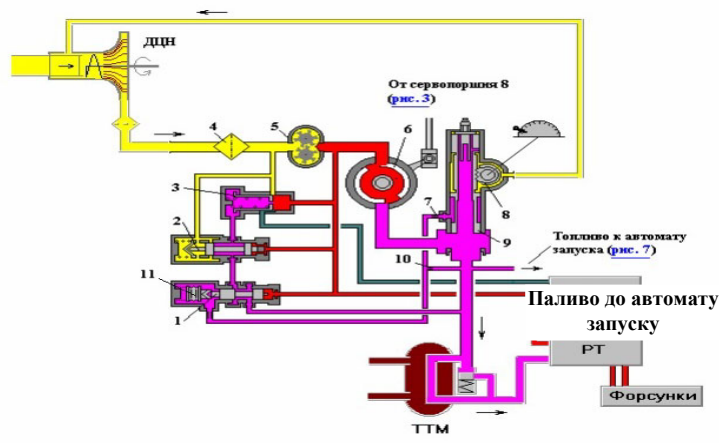

Рис. 7. Чутливий елемент ТЖ-5 (поз. 11) у вузлі агрегату НР-31В (принципова схема).

Джерело: розроблено авторами за даними [5, с. 111].

Випадків відмови агрегатів в експлуатації через руйнування термокомпенсаторів ТЖ-5 не було.

Таким чином, чутливі елементи агрегатів двигуна експлуатуються в межах встановленого pecyрсу цих агрегатів. Фактичний технічний стан вузлів та деталей агрегатів двигуна можна виявити лише при дослідженні їх технічного стану в умовах АРП після розбирання на складові частини та проведення дефектування. При цьому окремо звертається увага на дефекти та несправності, що обумовлені впливом строку служби.

Якщо за результатами досліджень технічного стану агрегатів, капітальний ремонт яких не передбачено, буде встановлено, що збільшення їх ресурсу неможливо без виконання ремонту, а також буде підтверджено можливість та доцільність його КР, необхідно підготувати рішення Міністерства оборони України щодо освоєння такого ремонту у відповідності до наказу Міністерства оборони України від 16.07.2015 № 343.

Нормативно-правовою базою організації таких досліджень та робіт є наказ Міністерства оборони України від 16.02.2015 № 68 “Про затвердження Порядку продовження (збільшення) встановлених показників виробів авіаційної техніки державної авіації, за якими не здійснюється авторський нагляд", який зареєстровано в Міністерстві юстиції України 03.03.2015 за № 244/26689 та рішення Міністерства оборони України від 11.04.2016 № АЛ-21Ф-3/АЛ-31Ф/РД-33/16/ПС "Про організацію досліджень та робіт 3 визначення можливості та умов збільшення ресурсу комплектувальних агрегатів авіаційних двигунів АЛ-21Ф-3, АЛ-31Ф, РД-33”.

Останнім часом методологію встановлення та підтвердження ресурсу АіКВ називають стратегією управління ресурсом (СУР) [6, с. 12].

СУР - це сукупність методів установлення pecyрсу та методів ї експлуатації. Вибір та 
застосування стратегії управління ресурсом визначається досягнутим рівнем досконалості АіКВ, адекватністю математичного моделювання фізичних процесів теплового та термомеханічного навантаження їх деталей, їх зносу, зміни властивостей матеріалів під дією пошкоджуючих факторів, які в них відбуваються, застосованими методами та засобами технічного діагностування тощо $[7$, с. $107 \ldots 119 ; 8$, с. $50 \ldots 55 ; 9$, с. $53 \ldots 57$; 10 , c. $4 \ldots 15 ; 11$, с. $30 \ldots 38]$.

Управління ресурсами АіКВ ГТД здійснюється за наступними стратегіями $[1$, с. $276 ; 6$, с. 36 ; 12 , с. 36,37$]$ (таблиця 2).

Таблиця 2 Основний зміст та відмінності стратегій управління ресурсами АіКВ авіаційних ГТД

\begin{tabular}{|c|c|}
\hline СУР(a) & $\begin{array}{l}\text { Встановлення та збільшення всіх видів } \\
\text { ресурсів (ВР, Р1КР*, МРР*) здійснюється } \\
\text { на підставі результатів ресурсних } \\
\text { випробувань, досвіду експлуатації та } \\
\text { розрахунків довговічності. Експлуатація } \\
\text { АіКВ здійснюється } 3 \text { обов’язковим } \\
\text { зняттям при відпрацюванні будь-якого } \\
\text { встановлених видів ресурсу }\end{array}$ \\
\hline СУР(б) & $\begin{array}{l}\text { Встановлення та збільшення ВР АіКВ } \\
\text { здійснюється на підставі результатів } \\
\text { ресурсних випробувань. Експлуатація } \\
\text { АіКВ здійснюється за технічним станом } \\
\text { без обов'язкового зняття для ремонту до } \\
\text { досягнення ВР }\end{array}$ \\
\hline СУР(в) & $\begin{array}{l}\text { Встановлення та збільшення ВР АіКВ } \\
\text { здійснюється } \\
\text { експериментально обгрунтованих методів } \\
\text { розрахунку та узагальнення досвіду } \\
\text { експлуатації прототипу. Експлуатація } \\
\text { АіКВ здійснюється за технічним станом } \\
\text { без обов'язкового зняття для ремонту до } \\
\text { досягнення ВР }\end{array}$ \\
\hline СУР(г) & \begin{tabular}{lll}
\multicolumn{2}{c}{ Ресурси АіКВ не } & \multicolumn{2}{c}{ встановлюються. } \\
Експлуатація & АіКВ & здійснюється за \\
результатами & аналізу i узагальнення \\
статистичних даних по експлуатації парку \\
агрегатів 3 контролем рівня надійності.
\end{tabular} \\
\hline
\end{tabular}
Джерело: [6, с. 36].

Примітка: МРP*, Р1КР* - ресурси: міжремонтний, до 1-го КР.
В процесі виконання досліджень і робіт доцільно застосовувати принципи та методичні підходи, притаманні СУР(а) та СУР(б).

За результатами проведеного аналізу визначено, що пріоритетними є дослідження щодо визначення можливості продовження встановленого pecypcy АіКВ АЧЭ-99, АЧЭ-240, АЧМЭС-7, АЧЭ-202М та ТЖ-5. Для вказаних АіКВ розроблено відповідні програми досліджень.

Отже, за результатами досліджень для кожного 3 чутливих елементів необхідно визначити граничне значення встановленого ресурсу для умов штатної експлуатації двигуна АЛ-31Ф, застосування до них штатних методів i засобів експлуатаційного контролю i діагностування, a також діючих технологій їх відновлення або заміни в процесі заводського ремонту.

\section{Висновки}

1. Аналізуючи характер відмов агрегатів двигуна АЛ-31Ф, причиною яких імовірно $\epsilon$ несправності чутливих елементів, які виявити, враховуючи місця розташування, можливо лише при дослідженні в умовах АРП після розбирання на складові частини та проведення дефектування агрегату. При цьому $є$ можливість об'єктивно оцінити технічний стан деталей та комплектувальних виробів.

2. Аналіз результатів надійності, умов роботи чутливих елементів та аналітичне прогнозування вірогідності їх відмов попередньо вказує на можливості збільшення (продовження за технічним станом) встановленого ресурсу АЧЭ-240, АЧМЭС-7, ТЖ-5 - до 15\%, АЧЭ-99 - до 30\% (від встановленого ресурсу 900 годин) при виконанні капітального ремонту $з$ подальшим прийняттям обгрунтованого рішення щодо збільшення ресурсу.

\section{Список літератури}

1. Григорьев В.А., Кузнецов С.П., Гишваров А.С. Испьтание авиационных двигателей-М.: Машиностроение, 2009. - 504 с.

2. Гаденин М.М. Оценка влияния режимов нагружения на условия достижения предельных состояний и назначение запасов. Заводская лаборатория. Диагностика материалов. 2013, т. 79, № 10. - С. 65-70.

3. Рішення Міністерства оборони України від 11.04.2016 № АЛ-21Ф-3/АЛ-31Ф/РД-33/16/ПС “Про організацію досліджень та робіт з визначення можливості та умов збільшення ресурсу комплектувальних агрегатів авіаційних двигунів АЛ-21Ф-3, АЛ-31Ф, РД-33”, 2016. - 5 с.

4. Турбореактивный двухконтурный двигатель с форсажной камерой сгорания АЛ-31Ф / Под ред. Назарова А.А. М.: ВВИА им. проф. Н.Е.Жуковского, 1987. - 362 с.

5. Системы автоматического управления силовыми установками летательных аппаратов / Ю.А. Климентовский. Киев: КВІЦ, 2001. - 399 с.

6. Положение об установлении ресурсов и увеличении ресурсов и сроков службы газотурбинных двигателей военной авиации, их агрегатов и комплектующих изделий. - М.: ЦИАМ, 2005. - 80 с. 
7. Современные методы обеспечения прочностной надежности деталей авиационных двигателей / Под редакцией Ю.А. Ножницкого, Б.Ф. Шорра, И.Н. Долгополова - М.: ТОРУС ПРЕСС, 2010. - 456 с.

8. Беляев М.С., Горбовец М.А., Комарова Т.И. Способ испытаний и расчетное определение предела выносливости для горизонтального участка кривой усталости // Авиационные материалы и технологии, 2012. - № 3. - С. 50-55.

9. Швец Л.И., Челомбитько А.В. Применение математического моделирования при испытаниях опытных авиационных ГТД на высотных стендах // ЦИАМ 2001-2005. Основные результаты научно-технической деятельности. М.: ЦИАМ, 2005. - Т. №1. - С. 53-57.

10. ГОСТ 25 101-83. Расчет и испытания на прочность. Методы схематизации случайных процессов нагружения элементов машин и конструкций и статистического представления результатов. - М.: Изд-во стандартов, 1983. - 30 с.

11. Бармин О.В., Брусков В.А., Тюльпаков И.Н. Методический подход к индивидуальному исчислению фактического ресурса авиационных ГТД.. - Люберцы: ВИНИТИ, 2001. - Выпуск № 3. - С. 30-38.

12. Надежность и эффективность в технике: Справочник в 10 томах. - М.: Машиностроение, 1990. Т.8: Эксплуатация и ремонт / Под ред. В.Н. Кузнєцова, Е.Ю. Барзиловича, 1990.- 320 с.

Надійшла до редколегії 27.10.2021

Схвалена до друку 18.11.2021

\section{Відомості про авторів:}

\section{Бондар Андрій Васильович}

кандидат технічних наук

старший науковий співробітник

Державного науково-дослідного інституту авіації,

Київ, Україна

https://orcid.org/0000-0002-3350-4331

\section{Шумілін Геннадій Олександрович}

старший науковий співробітник

Державного науково-дослідного інституту авіації, Київ, Україна

https://orcid.org/0000-0002-6974-3692

\section{Агамова Раїса Геннадіївна}

молодший науковий співробітник

Державного науково-дослідного інституту авіації, Київ, Україна

https://orcid.org/0000-0002-9723-2988

\section{Information about the authors:}

\author{
Andrei Bondar \\ Candidate of Technical Sciences \\ Senior Researcher \\ of State Research Institute of Aviation, \\ Kyiv, Ukraine \\ https://orcid.org/0000-0002-3350-4331
}

\author{
Hennadii Shumilin \\ Senior Researcher \\ of State Research Institute of Aviation, \\ Kyiv, Ukraine \\ https://orcid.org/0000-0002-6974-3692
}

\author{
Raisa Ahamova \\ Junior Researcher \\ of State Research Institute of Aviation, \\ Kyiv, Ukraine \\ https://orcid.org/0000-0002-9723-2988
}

\title{
JUSTIFICATION OF CONDITIONS, NEEDS (EXPENDITURE) AND POSSIBILITIES OF INCREASE (CONTINUATION BY TECHNICAL CONDITION) OF THE INSTALLATED RESOURCE OF SENSITIVE SENSITIVES
}

\author{
A. Bondar, H. Shumilin, R.Ahamova
}

Operation and repair of aircraft engines and their components in Ukraine takes place in the absence of author's support from developers and manufacturers. Resources of units and accessories should be, as a rule, identical or exceed a resource of the engine. However, some units have a lower service life than the installed engine life. Therefore, there is a question about the possibility of using these units for the next service life. During operation, the units operate in different ranges of temperatures, pressures and loads. Therefore, the resource sensitive elements are different.

When repairing the AL-31F engine, it is necessary to replace units and components with a significant stock of installed resource and exhausted service life with new ones. To determine the possibility of extending the installed life of the units operated as part of the AL-31F engines, it is necessary to conduct a study of their technical condition during their overhaul in the conditions of the aircraft repair company. The next (second) overhaul of the aircraft engine allows identifying some problematic issues of ensuring the continued maintenance of the airworthiness of a given number of aircraft. This is, first of all, the substantiation of the technical possibility of increasing the installed life of the main parts of engines, mastering their production in Ukraine in the order of import substitution and ensuring safe operation of engines according to the technical condition of production.

Analyzing the nature of failures of AL-31F engine units, which are probably caused by malfunctions of sensitive elements, which can be detected, taking into account the location, only during the study in ARP conditions after disassembly into components and defect unit. At the same time, it is possible to objectively assess the technical condition of parts and components.

Analysis of the results of reliability, operating conditions of sensitive elements and analytical forecasting of the probability of their failures preliminarily indicates the possibility of increasing (continuation of the technical condition) of the installed resource AChE-240, AChMES-7, TZh-5 - up to 15\%, AChE-99 - up to $30 \%$ (from the installed resource of 900 hours) when performing overhaul with the subsequent adoption of a reasoned decision to increase the resource.

Keywords: aircraft engine, sensitive elements, resource management strategy, installed resource, malfunction. 